\title{
Potential predation and fecundity of Amblyseius aerialis fed two-spotted spider mite
}

\author{
Anilde da Graça Sousa Maciel ${ }^{*}$, Roseane Cristina Predes Trindadel, \\ Edmilson Santos Silva', Márcia Daniela dos Santos'
}

'Federal University of Alagoas, Maceió, Brazil

${ }^{*}$ Corresponding author, email: maciel_anilde@hotmail.com

\begin{abstract}
The mites of the Phytoseiidae family stand out for the biological control of pest mites. The species Amblyseius aerialis (Muma, 1955) is a generalist mite, which can contribute to the natural regulation of pest mites. The objective of this study was to evaluate the potential for predation and fecundity of A. aerialis on the different phases of Tetranychus urticae (Koch, 1836) (Acari: Tetranychidae). A female of A. aerialis was confined on dish $(3.0 \mathrm{~cm}$ in diameter) of jack bean leaves, Canavalia ensiformis (L.) DC. The discs were left in petri dish with water. Each T. urticae phase was offered individually to A. aerialis at densities: 2, 5, 10, 15, 20 and 30 mites / arena. The number of prey consumed and eggs laid by $A$. aerialis were evaluated every 24 hours for seven days, with removal of laid eggs by phytoseiid and dead prey and replacement of prey in the initial amount. The data were submitted to analysis of variance and the means were compared by Tukey test, applying the factorial $(4 \times 6)$. It was observed that with the increase of the density of $T$. urticae offered there was an increase in the predation of $A$. aerialis. When offered the nymph and adult the average number of eggs per day was higher, differing from egg and larva. Thus, A. aerialis can be a biological control agent of the $T$. urticae, reducing the population of the pest and maintaining its fecundity in all phases and densities offered.
\end{abstract}

Keywords: pests mites, predatory mite, biological control

\section{Introduction}

The mite Amblyseius aerialis (Muma, 1955) belonga to the family Phytoseiidae and is a generalist predator of group III, which feeds on other mites, as well as insects and pollen (Moraes \& Flechtmann, 2008). This species has been reported in fruit crops (Silva et al., 2010), rose bushes (Forero et al., 2008), coffee plantations, and forest fragments (Silva et al. 2010).

Some biological characteristics of this mite have been studied, including its survival when fed with different types of prey such as phytophagous mites Phyllocoptruta oleivora (Ashmead, 1879) (Eriophidae) (Batista \& Noronha, 2008) and Brevipalpus phoenicis

(Geijskes, 1939) (Tenuipalpidae) and plant pollen of Ricinus communis L. (Euphorbiaceae) and Typha angustifolia L. (Typhaceae) (Castillo \& Noronha, 2008). However, little is known about its ability to reduce populations of the two-spotted spider mite, Tetranychus urticae (Koch, 1836) (Tetranychidae).

The two-spotted spider mite can occur in cotton, beans, corn, soybean, papaya, apple, grape, lettuce, potato, eggplant, watermelon, melon, strawberry, cucumber, tomato crops, as well as ornamental plants. High infestations can cause loss of photosynthetic capacity, due to the discoloration and premature fall of the leaves, as well as damage the quality of fruits 
because of sun exposure. In some fruits, it can reduce production by up to $80 \%$ at the peak of population development when uncontrolled (Naher \& Haque, 2007; Moraes \& Flechtmann, 2008, Badawy et al., 2010).

This mite is primarily control with chemical acaricides, which are not always efficient, because inappropriate management of these products facilitates the selection of resistant populations and increases the risk of environmental contamination and intoxication of the applicator (Sato et al. 2007; Carvalho et al., 2012). In addition, chemicals may cause the resurgence of pests as it also kills predatory mites and other natural enemies (Marsaro Júnior et al., 2012).

Biological control using mites from the Phytoseiidae family has been widely discussed. Mites of this family are effective biological control agents, which are marketed and used in Integrated Pest Management programs (Gerson \& Weintraub, 2007; Cakmak et al., 2009).

Phytoseiid mites, when abundant in the crop, can keep the population of pest mites below the economic injury level, avoiding or mitigating the application of chemical acaricides, reducing selection pressure, and consequently slowing the development of resistance (Marafeli, 2011).

Hence, the objective of this work was to evaluate the potential for predation and fecundity of A. aerialis, fed on eggs, larvae, nymphs, and adults of $T$. urticae at different densities.

\section{Material and methods}

Collection and rearing the Amblyseius aerialis mite

The predatory mite A. aerialis was obtained on jack bean Canavalia ensiformis (L.) DC. (Fabaceae) plants infested with T. urticae, collected in a greenhouse at the Agricultural Sciences Center (CECA) of the Federal University of Alagoas (UFAL), in Rio Largo, AL, Brazil. Slides with mite specimens were sent to the Acarology Laboratory of the Luiz de Queiroz College of Agriculture (ESALQ) at the University of São Paulo, in Piracicaba, SP, Brazil for specialists to identify.

The predatory mite A. aerialis was kept in the Laboratory of Entomology/Alternative Control of CECA/UFAL in climatic conditions at 26 $\pm 1{ }^{\circ} \mathrm{C}, 60 \pm 10 \% \mathrm{RH}$, and $12 \mathrm{~h}$ photophase.

The rearing method was that used by Reis \& Alves (1997), in which the mites were confined in arenas made from jack bean leaves $15.0 \mathrm{~cm}$ in diameter). The arenas were placed to float over distilled water in uncovered Petri dishes (8.5 $\mathrm{cm}$ in diameter). Each arena had a hole in the center to pass a pin. The pins were fixed with the head facing the bottom of the board with the aid of silicone-based glve. A piece of transparent pyramid-shaped plastic was placed in the arenas for the mites to shelter and oviposition. T. urticae was used in all stages in abundance as a food source. The arenas were changed every seven days or when the food source for predatory mites, i.e., T. urticae, was low. The predatory mites were transferred to new arenas infested with $T$. urticae with the aid of a fine-bristled brush.

Predation and fecundity of Amblyseius aerialis fed with two-spotted spider mite

To evaluate predation and fecundity,

A. aerialis was observed from one-day old eggs until the adult phase. Then, from this group, adult females were fecundated by confinement for seven days in $3.0 \mathrm{~cm}$ diameter arenas made from jack bean leaves (Onzo et al., 2012). Each arena was considered a repetition. The arenas were kept in Petri dishes (8.5 cm in diameter), similar to those used to rear the mite.

During each stage (egg, larva, nymph, and adult) of the two-spotted spider mite was individually offered to the $A$. aerialis mite. The prey was placed at the following densities: 2, 5, 10, 15 (eight repetitions); 20 and 30 mites/arena (five repetitions). The number of repetitions were less when the densities of $T$. urticae increased due to the difficulty of dealing with so many mites (Reis et al., 2003).

The number of prey consumed and the number of eggs layed by $A$. aerialis phytoseiid mites were evaluated every $24 \mathrm{~h}$ for seven days, with the removal of the eggs deposited by the phytoseiid and the dead prey and the prey replaced at the initial amount (Reis et al., 2003). In the treatment that supplied the $T$. urticae adult females, the eggs of $T$. urticae preyed on 
by A. aerialis were also quantified by observing the egg chorion left by the predator. After each evaluation, the remaining $T$. urticae eggs, not preyed on, were removed to avoid hatching during the evaluation of the experiment.

The data were submitted to analysis of variance and the means were compared by Tukey's test, at $5 \%$ probability, using the factorial scheme $(4 \times 6)$, by the SAS statistical program (SAS Institute 2003). And the data obtained concerning the density of preyed on mites were submitted to regression analysis.

\section{Results and discussion}

Interaction was found between phase and density of the T. urticae mite by the predatory A. aerialis mite, with a significant difference ( $F$ $=57.65 ; p \leq 0.001)$. When the density of the $T$. urticae increased, the predation by $A$. aerialis also increased (Figure 1 and Table 1).

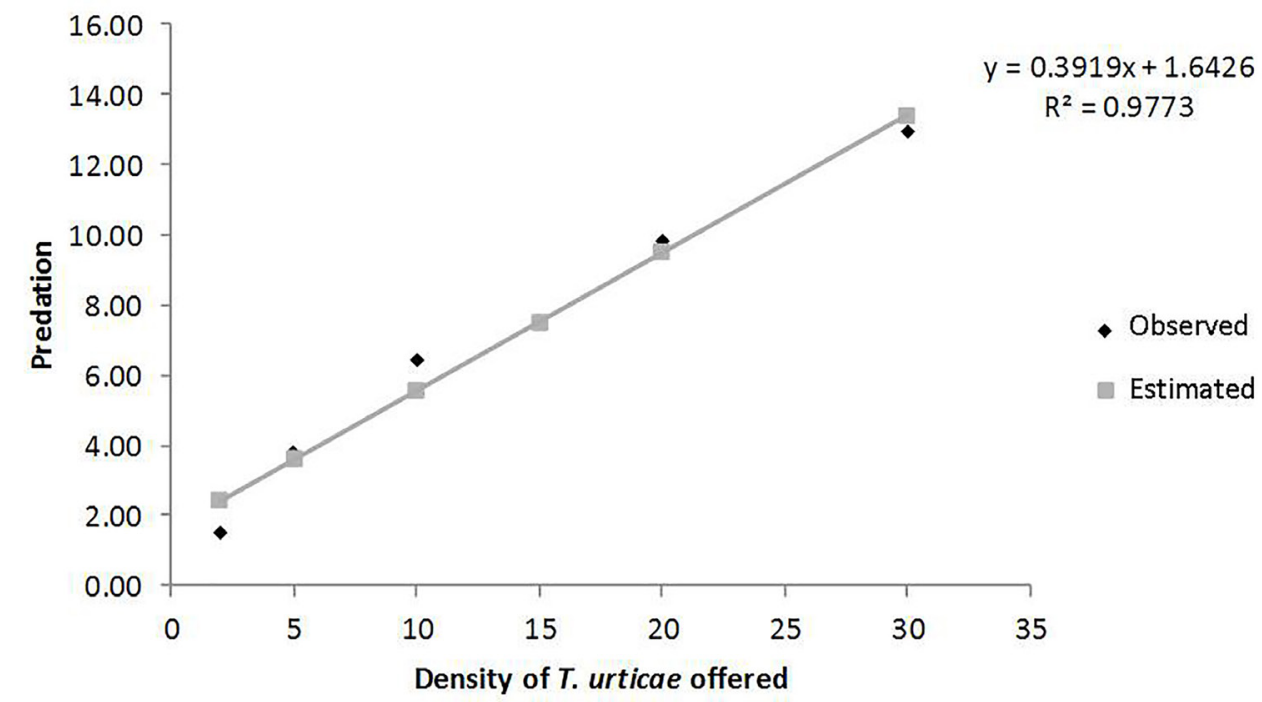

Figure 1. Predation of the mite Amblyseius aerialis in relation to the density of $T$. urticae offered.

Table 1. Number of Tetranychus urticae mites preyed on (mean \pm SD) in different phases and densities offered by Amblyseius aerialis mites

\begin{tabular}{|c|c|c|c|c|c|c|c|}
\hline \multirow[b]{2}{*}{ Phases } & \multicolumn{6}{|c|}{ Density offered' } & \multirow[b]{2}{*}{$\begin{array}{c}F^{F} \\
p \leq 0.001\end{array}$} \\
\hline & 2 & 5 & 10 & 15 & 20 & 30 & \\
\hline Egg & $1.91 \pm 0.17 \mathrm{aD}$ & $4.43 \pm 0.60 \mathrm{aD}$ & $8.98 \pm 0.70 a C$ & $10.84 \pm 1.06 \mathrm{bBC}$ & $13.60 \pm 3.27 \mathrm{aAB}$ & $14.83 \pm 3.28 \mathrm{bA}$ & 50.61 \\
\hline Larva & $1.80 \pm 0.21 \mathrm{aF}$ & $4.71 \pm 0.30 \mathrm{aE}$ & $9.02 \pm 1.14 \mathrm{aD}$ & $13.43 \pm 1.00 \mathrm{aC}$ & $17.46 \pm 3.60 \mathrm{aB}$ & $27.37 \pm 1.96 \mathrm{aA}$ & 223.82 \\
\hline Nymph & $1.53 \pm 0.33 \mathrm{aC}$ & $4.18 \pm 0.38 a B$ & $4.36 \pm 0.74 \mathrm{bB}$ & $3.80 \pm 0.89 \mathrm{CB}$ & $5.99 \pm 0.71 \mathrm{bA}$ & $6.60 \pm 1.90 \mathrm{cA}$ & 26.67 \\
\hline Adult & $0.87 \pm 0.48 a C$ & $1.86 \pm 0.53 \mathrm{bBC}$ & $3.23 \pm 0.93 \mathrm{bA}$ & $2.00 \pm 0.51 \mathrm{~dB}$ & $2.28 \pm 0.33 \mathrm{bAB}$ & $2.88 \pm 1.04 \mathrm{CAB}$ & 11.57 \\
\hline $\begin{array}{c}F \\
p \leq 0.001\end{array}$ & 16.70 & 62.50 & 91.76 & 152.47 & 39.66 & 121.75 & \\
\hline
\end{tabular}

When the adult phase of $T$. urticae was offered, oviposition of T. urticae occurred; therefore, the A. aerialis mite preyed on the $T$. urticae eggs. The mean egg consumption in this adult treatment was $4.73 \pm 0.65 ; 6.52 \pm 0.56 ; 6.20$ $\pm 0.60 ; 8.50 \pm 0.53 ; 7.28 \pm 0.68$; and $7.34 \pm 0.49$, at densities of $2,5,10,15,20$, and 30 , respectively (the data were counted separately). Egg consumption probably interfered with the number of adults consumed, which was lower in relation to the other phases (Table 1).

At density 2, the predator mite consumed similar number of mites regardless of the T. urticae phase offered, with a mean predation of $1.91 \pm$ $0.17 ; 1.80 \pm 0.21 ; 1.53 \pm 0.33$; and $0.87 \pm 0.48$ of eggs, larvae, nymphs, and adults, respectively. At density 5, the egg, larva, and nymph phases were similar with predation of $4.43 \pm 0.60 ; 4.71 \pm$ 0.30 ; and $4.18 \pm 0.38$ mites/day, respectively. Only the adult phase had lower predation of $1.86 \pm$ 0.53 mite/day (Table 1).

At density 10, egg and larva stages experienced the highest mean predation, at 8.98 \pm 0.70 and $9.02 \pm 1.14$, respectively. The nymph 
and adult phase of $T$. urticae, when offered at this density, had similar predation of $4.36 \pm 0.74$ and $3.23 \pm 0.93$ mite/day, respectively (Table 1). At density 15, a difference occurred in all phases offered for mean predation. The predatory consumed larvae (13.43 \pm 1.00$)$, followed by egg (10.84 \pm 1.06 ), nymph (3.80 \pm 0.89 ), and adult (2.00 \pm 0.51 ) (Table 1). At density 20, eggs and larvae were similar to each other, with a mean of 13.60 \pm 3.27 and $17.46 \pm 3.60$, respectively. Nymphs and adults were also similar to each other, with a mean of $5.99 \pm 0.71$ and $2.28 \pm 0.33$, respectively.

At density 30, the larvae experienced the highest predation of $27.37 \pm 1.96$ mites/ day, followed by phases egg (14.83 \pm 3.28$)$. The nymph and adult phases were similar $(6.60 \pm 1.90$ and $2.88 \pm 1.04$ ) (Table 1).

The fecundity of the A. aerialis mite was significantly different when fed by different stages of the $T$. urticae mite at different densities $(F=2.55, p=0.002)$ (Table 2).

Table 2. Fecundity (mean $\pm S D$ ) of the Amblyseius aerialis mite in relation to the densities and phases of the twospotted spider mite

\begin{tabular}{|c|c|c|c|c|c|c|c|}
\hline \multirow{2}{*}{ Phases } & \multicolumn{6}{|c|}{ Densidade ofertadas ${ }^{1}$} & \multirow[b]{2}{*}{$p$} \\
\hline & 2 & 5 & 10 & 15 & 20 & 30 & \\
\hline Egg & $0.18 \pm 0.07 \mathrm{bA}$ & $0.23 \pm 0.07 \mathrm{bA}$ & $0.23 \pm 0.11 \mathrm{cA}$ & $0.23 \pm 0.13 \mathrm{bA}$ & $0.26 \pm 0.12 \mathrm{bA}$ & $0.20 \pm 0.08 \mathrm{bA} \quad 0.54$ & 0.74 \\
\hline Larva & $0.16 \pm 0.09 \mathrm{bA}$ & $0.23 \pm 0.07 \mathrm{bA}$ & $0.23 \pm 0.11 \mathrm{cA}$ & $0.23 \pm 0.13 \mathrm{bA}$ & $0.26 \pm 0.12 \mathrm{bA}$ & $0.20 \pm 0.08 \mathrm{bA} \quad 0.77$ & 0.58 \\
\hline Nymph & $0.60 \pm 0.27 a B$ & $1.00 \pm 0.35 a A B$ & $1.28 \pm 0.30 \mathrm{aA}$ & $0.93 \pm 0.39 a A B$ & $1.03 \pm 0.06 \mathrm{aAB}$ & $1.14 \pm 0.17 a A \quad 4.42$ & 0.003 \\
\hline Adult & $0.46 \pm 0.26 \mathrm{aB}$ & $0.80 \pm 0.24 a A B$ & $0.78 \pm 0.34 \mathrm{bAB}$ & $0.96 \pm 0.21 \mathrm{aA}$ & $0.86 \pm 0.23 a A B$ & $1.03 \pm 0.31$ aA 3.86 & 0.006 \\
\hline $\begin{array}{c}F^{F} \\
p \leq 0.001\end{array}$ & 9.89 & 26.04 & 35.32 & 23.54 & 38.53 & 37.92 & \\
\hline
\end{tabular}

For all densities, when the nymph and adult phase were offered, the mean egg /day was higher, differing significantly from the egg and larva phases. When offered the egg and larva phases, mean eggs/day were significantly equal throughout the offered densities (Table 2).

When the nymph stage was offered at density 2 , mean egg/day was $0.60 \pm 0.27$ and was significantly equal to density 5,15 , and 20 with mean values of $1.00 \pm 0.35 ; 0.93 \pm 0.39 ; 1.03 \pm$ 0.06 egg/day, respectively. These values, in turn, were similar at densities 10 and 30 , with $1.28 \pm 0.30$ and $1.14 \pm 0.17$, respectively (Table 2 ).

When the adult phase was offered at density 2 , mean egg/day of $0.46 \pm 0.26$ was significantly equal to density 5,10 , and 20 with mean values of $0.80 \pm 0.24 ; 0.78 \pm 0.34 ; 0.86 \pm 0.23$ egg/day, respectively. In turn, densities at 15 and 30 were similar, with $0.96 \pm 0.21$ and $1.03 \pm 0.31$ respectively (Table 2 ).

The predation potential of the A. aerialis mite was higher on the egg and larvae stage of $T$. urticae, at density 10 and above, which is probably due to the small size of these phases and because they are less agile (in the case of the larvae) or stationary (in the case of eggs), compared to the other stages. Similar results were observed for the predatory mite Euseius alatus (De
Leon, 1966) (Phytoseiidae), which more intensely preyed on larva and nymph of Oligonychus ilicis (McGregor, 1917) (Tetranychidae) (Toledo et al., 2013). Similarly, the predatory mite Neoseiulus californicus (McGregor, 1954) (Phytoseiidae) preferred the larva stage of $T$. urticae (Marafeli et al., 2011).

The rate of predator consumption is generally inversely related to the size of prey (Kasap \& Atlihan 2011). However, in the present study, the percentage of predation on eggs at densities 15 and 30 was lower in relation to predation in larvae, although eggs are smaller and immobile. According to Blackwood et al. (2001), generalist predatory mites have difficulty breaking the egg chorion because they may have less effective mouthparts than specialist predatory mites.

The adult phase of $T$. urticae presented a lower percentage of predation, in addition to being larger and more agile, their oviposition led in consumption of these eggs by the predator mite, which caused and underestimate of the predation potential (Costa et al., 2014). Similar results were observed with the predator mite Euseius Concordis (Chant, 1959) (Phytoseiidae), when being offered Mononychellus Tanajoa (Bondo, 1938) (Tetranychidae) as food (Costa et 
al., 2014).

Other authors have observed that the predatory mite $N$. californicus, which is also a generalist, preyed on more larvae and nymphs per day of Tetranychus kanzawai and T. urticae compared to Neoseiulus longispinosus, which preferred eggs of these tetranychida mites (Song et al., 2016).

Souza-Pimentel et al. (2014) found that $N$. californicus was efficient when released on rose leaves infected with $T$. urticae. The pest mite population reduced with the increase of $\mathrm{N}$. californicus on leaves.

In the present study, although the predation rate was higher on the egg and larva phases, these phases had a lower mean egg/ day, compared to the nymph and adult phases, as the egg and larva stages may have provided less energy for good fecundity in the predatory mite A. aerialis. Costa et al., 2014 found the opposite results, in which a higher oviposition rate was observed when the predatory mite $E$. concordis consumed $M$. tanajoa eggs than with the other phases.

Although the nymph and adult phases were consumed in a smaller amount, they are larger and may provide the necessary resources for more eggs/day by A. aerialis mite. Another situation that probably produced these results in the adult phase was that the predatory mites also fed on T. urticae eggs laid throughout the experiment. This fact may have increased the energy gain and benefited the oviposition rate.

One of the advantages of controlling pest mites with generalist predator mites is the persistence of the predatory mite in the crop area even in the absence or low density of the pest mite. This is an important feature in pest management programs, since their diverse food consumption may facilitate their permanence in the crop for a longer period without the pest (Marafeli, 2011).

\section{Conclusions}

A. aerialis predator mites increase their predation rate when the number of $T$. urticae mites also increases. A mean of up to one egg/ day was observed when fed on the different phases of the T. urticae mite. Thus, this species can be a biological control agent of the $T$. urticae mite, reducing the population of the pest while maintaining its own fecundity.

\section{References}

Badawy, M.E.I, El-Arami, S.A.A., Abdelgaleil, S.A.M. 2010. Acaricidal and quantitative structure activity relationship of monoterpenes against the two-spotted spider mite, Tetranychus urticae. Experimental \& Applied Acarology 52: 261-274.

Batista, A.A., Noronha, A.C.S. 2008. Manejo de ácaros fitófagos em citros com aplicação de métodos de controle de baixo impacto ambiental. In: $2^{\circ}$ Jornada Científica. Embrapa Mandioca e Fruticultura Tropical.

Blackwood, J.S., Schausberger P., Croft B. A. 2001. Prey-stage preference in generalista and specialist phytoseiid mites (Acari: Phytoseiidae) when offered Tetranychus urticae (Acari: Tetranychidae) eggs and larvae. Environmental Entomology 30: $1104-1111$.

Bobot, T.E., Franklin, E., Navia, D., Gasnier, T.R.J., Lofego, A.C., Oliveira, B.M. 2011. Mites (Arachnida, Acari) on Citrus sinensis L. Osbeck orange trees in the state of Amazonas, Northern Brazil. Acta Amazonica 41: 557-566.

Cakmak, I., Janssen, A., Sabelis, W.M., Baspinar, H., 2009. Biological control of na acarine pest by single and multiple natural enemies. Biological Control 50: 60- 65.

Carvalho, L.M., Almeida, K., Taques, T.C., Soares, C.S.A., Almeida, E.F.A., Reis, S.N. 2012. Manejo de pragas em cultivo de roseira de sistema de produção integrada e sistema convencional. Bioscience Journal 28: 938944.

Castillo, A.B., Noronha, A.C.S. 2008. Estudio de los aspectos fundamentales de la biologia de Amblyseius aerialis (Muma) (Acari: Phytoseiidae) en condiciones de laboratório. Revista Citrifrut 25: 45-62.

Costa, E.C., Teodoro, A.V., Rêgo, A.S., Pedro Neto, M., Sarmento, R.A. 2014. Functional response of Euseius concordis to densities of different developmental stages of the cassava green mite. Experimental \& Applied Acarology 64: $277-286$.

Forero, G., Rodríguez, M., Cantor, F., Rodríguez, D., Cure, J.R. 2008. Criterios para el manejo de Tetranychus urticae Koch (Acari: Tetranychidae) con el ácaro depredador Amblyseius (Neoseiulus) sp. (Acari: Phytoseiidae) em cultivos de rosas. Agronomía Colombiana 26: 1-17.

Gerson, U., Weintraub, P.G. 2007. Mites for the control of pests in protected cultivation. Pest Management Science 63: 658-676. 
Kasap, I., Atlihan, R. 2011. Consumption rate and functional response of the predaceous mite Kampimodromus aberrans to two-spotted spider mite Tetranychus urticae in the laboratory. Experimental \& Applied Acarology, 53, 253-261.

Marafeli, P.P. 2011 . História de vida de Neoseiulus californicus (MC GREGOR, 1954) tendo como alimento Tetranychus urticae Koch, 1836 (Acari: Phytoseiidae, Tetranychidae) e pólen de mamona (Ricinus communis L.). 75f. Dissertação de Mestrado - Universidade Federal de Lavras, Lavras, Brasil.

Marafeli, P.P., Reis, P.R., Silveira, E.C., Toledo, M.A., Souza-Pimentel, G.C. 2011. Neoseiulus californicus (McGregor, 1954) preying in diferente life stages of Tetranychus urticae Koch, 1836 (Acari: Phytoseiidae, Tetranychidae). Acarologia 51: 499-506.

Marsaro Júnior, A.L., Sato, M.E., de Aguiar, R.M., Vieira, G.B., da Silva, Júnior R.J., Mineiro, J.L.C. 2012. Efeito de acaricidas sobre Schizotetranychus hindustanicus (Hirst) (Acari: Tetranychidae) e ácaros predadores em citros no estado de Roraima, Brasil. Arquivos do Instituto Biológico 79:75-83.

Mineiro, J.L.C., Silva, W.R., Silva, R.A. 2012. Ácaros em fruteiras e outras plantas no Estado de Amapá. Biota Neotropical 9: 103-106.

Moraes, G.J., Flechtmann, C.H.W. 2008. Manual de Acarologia. Acarologia básica e ácaros de plantas cultivadas no Brasil. Holos, Ribeirão Preto, Brasil, 308 p.

Naher, L., Haque, M. 2007. Biological Control of Tetranychus urticae (Acari: Tetranychidae) Using Phytoseiullus persimilis (Acari: Phytoseiidae). Research Journal of Biological Sciences 3: 550553.

Noronha, A.C.S., Argolo, P.S., Boaventura, V.J., Ritzinger, R. 2010. Ácaros (Acari) em mudas de aceloreira. Boletín de Sanidad Vegetal Plagas 36: 189-195.

Onzo, A., Houedokoho, A.F., Hanna R. 2012. Potential of the predatory mite, Amblyseius swirskii to suppress the broad mite, Polyphagotarsonemus latus on the gboma eggplant, Solanum macrocarpon. Journal of Insect Science 12: 1-11.

Reis P.R., Alves E.B. 1997. Criação do ácaro predador Iphiseiodes zuluagai Denmark Muma (Acari: Phytoseiidae) em laboratório. Anais da Sociedade Entomológica do Brasil 26: 565-56.

Reis, P.R., Sousa, E.O., Teodoro, A.V., Pedro Neto, M. 2003. Effect of prey density on the functional and numerical responses of two species of predaceous mites (Acari: Phytoseiidae). Neotropical Entomology 32: 461-467.
SAS Institute Inc.Statistical Analysis System user's guide, version 9.1, Ed. Cary: Institute, USA, 2003.

Sato, M.E., da Silva, M.Z., Cangani, K.G., Raga, A. 2007. Seleções para resistência e suscetibilidade, detecção e monitoramento da resistência de Tetranychus urticae ao acaricida Clorfenapir. Bragantia 661:89-95.

Silva, E.A., Reis, P.R., Zacarias, M.S., Marafeli, P.P. 2010. Fitoseídeos (Acari: Phytoseiidae) associados à cafezais e fragmentos florestais vizinhos. Ciências e Agrotecnologia 34: 11461153.

Silva, F.A.S; Azevedo, C.A.V. 2009. Principal Components Analysis in the Software AssistatStatistical Attendance. In: World Congresson Computers in Agriculture, 7, RenoNV-USA: American Society of Agricultural and Biological Engineers 393-396.

Song, Z., Zheng, Y., Zhang, B., Li, D. 2016. Prey consumption and functional response of Neoseiulus californicus and Neoseiulus longispinosus (Acari: Phytoseiidae) on Tetranychus urticae and Tetranychus kanzawai (Acari: Tetranychidae) Systematic \& Applied Acarology 21: 936-946.

Souza-Pimentel, G.C., Reis, P.R., Silveira, E.C., Marafeli, P.P., Silva, E.A., Andrade, H.B. 2014. Biological control of Tetranychus urticae (Tetranychidae) on rosebushes using Neoseiulus californicus (Phytoseiidae) and agrochemical selectivity. Revista Colombiana de Entomología 40: 80-84.

Toledo, M.A., Reis, P.R., Silveira, E.C., Marafeli, P.P., Souza-Pimentel, G.C. 2013. Predatory potential of Euseius alatus (Phytoseiidae) on different life stages of Oligonychus ilicis (Tetranychidae) on coffee leaves under laboratory conditions. Neotropical Entomology 42: 185-190. 